\title{
Experimentalizing the organization of objects: Re-enacting mines and landfills
}

Nils Johansson and Jonathan Metzger

\author{
Linköping University Post Print
}

Tweet

N.B.: When citing this work, cite the original article.

Original Publication:

Nils Johansson and Jonathan Metzger, Experimentalizing the organization of objects: Reenacting mines and landfills, 2016, Organization.

http://dx.doi.org/10.1177/1350508415624271

Copyright: SAGE Publications (UK and US)

http://www.uk.sagepub.com/home.nav

Postprint available at: Linköping University Electronic Press

http://urn.kb.se/resolve?urn=urn:nbn:se:liu:diva-124415 


\title{
Experimentalizing the organization of objects: re-enacting mines and landfills
}

\begin{abstract}
In this paper we draw upon "After-ANT" scholarship to generate openings for a shift from purely deconstructive studies of object organization to a more straightforward generation of concrete and specific alternative trajectories towards the future by way of ontological experimentation. Through careful empirical investigation of a mine and a landfill, and how these are enacted in practice in different topological registers, we show how mines and landfills are intertwined; enacted sometimes as similar and in other cases as different types of object, thus shaping the paths of becoming for those bundles of relations that become enacted as either a "mine object" or a "landfill object." Mapping these practices generates openings for interventions suggesting how things could be made different in some specificity; in this case e.g. the appreciation of what constitutes "natural resources." The overarching purpose of the paper is to intervene in current debates regarding the potential merits of drawing upon Object-Oriented Philosophy (OOP) as an inspiration in critical organizational studies. While we are highly sympathetic to calls for more experimental object studies, we are hesitant towards OOP as a source of inspiration due to its specific metaphysical underpinnings. To clarify what we find to be at stake here, we conclude the paper by situating After-ANT in a wider landscape of thought, discussing the contrast between broadly pragmatist research approaches, such as After-ANT, and OOP. Finally we try to spell out how we believe this contrast reverberates upon how we understand the purpose and potential of critical social science.
\end{abstract}

Key Words: After ANT, Object-Oriented Philosophy, topology, mining, metals, ontological experimentation.

"We need to think more carefully about the nature of the objects in the world-about what counts as an object" - Law \& Singleton (2005), p. 334.

"Here's the proposition: In this way of thinking, politics is about interfering to make a difference. And, perhaps should I add, it is about being sufficiently modest to resist the idea that there is a single or explicit mode of ordering the world" - Law (2009a), p. 11.

\section{Introduction}

In an important contribution to critical management and organizational studies, Spicer et al. (2009) argue for a more explicit focus on scholarly work that aims at generating "critical performativity." This they understand as "active and subversive intervention into managerial discourses and practices," achieved through "affirmation, care, pragmatism, engagement with potentialities and a normative orientation," the aim of which is to "move beyond cynicism" and "create social change" (Spicer et al., 2009:538). As previously noted by Alcadipani \& Hassard (2010) in the pages of this journal, research work within the ANT tradition has repeatedly been accused of generating depoliticizing apologias for current organizational practices in particular, or the existing state of things in general, and as such not contributing with any critical performativity. Alcadipani \& Hassard disagree with these claims, and particularly highlight recent developments in so-called ANT and After scholarship ("After-ANT") to argue that ANT possesses a strong potential for critical performativity through highlighting how "organizational realities are not the given order of things and as such could be otherwise" (Alcadipani \& Hassard, 2010: 426; see also Woolgar \& Lezaun, 2013).

Exploring this intuition further, and perhaps to some degree pushing it to its limit, in this paper we draw upon After-ANT scholarship to try to show how the above insight from Alcadipani \& Hassard reaches all the way into the apparent nuts and bolts of reality - the practices that incessantly work towards organizing the world into a world of objects. Already in the very early beginnings of ANT, scholars such as Bruno Latour and John Law developed conceptual innovations such as "blackboxing" (Latour, 1987) and "punctualization" (Law, 1992) to engender empirical investigations into how 
objects become constructed as discrete and specific entities. Within this research approach, later work by scholars such as John Law, Annemarie Mol and Vicky Singleton have, by way of inspiration from e.g. postcolonial studies, feminist theory and pragmatist as well as poststructuralist philosophy, turned towards even deeper investigations of how objects are enacted in and through practices. Woolgar \& Lezaun (2013: 323) argue that this vein of what is sometimes referred to as "ANT and After" or "After-ANT" scholarship draws "critical attention to objects that might otherwise appear 'finished' or 'ready-made,' to scrutinize those entities that a conventional STS analysis would often consider 'black-boxed' and no longer controversial." Focusing on the enactment of objects thus emphasizes the "generative power of the practices involved in the constitution of reality," forcing us to further keep in mind that seemingly straightforward 'materiality' - i.e. the physical identity, durability, obduracy and recalcitrance of material objects - should also be treated as practical achievements: "the contingent upshot of practices, rather than a bedrock reality to be illuminated by an ontological investigation" (Woolgar \& Lezaun, 2013: 324).

Based on the above, After-ANT scholarship could be said to generate affordances for fusing an interest in epistemological and ontological reflexivity with an affirmation of the inherently political character of critical management and organizational studies that Spicer et al. (2009) call for. AfterANT thus pushes critical performativity into the realm of "ontological politics" (Mol, 1999) or "cosmopolitics" (Latour, 2004) by challenging the givenness of that which we call "reality," and engendering critical reflection on how ideas about what is "real" co-evolve with (and are fundamentally implicated in) ideas about what constitutes possible or desirable future developments (Alcadipani \& Hassard, 2010).

In this paper we want to make use of the onto-political affordances opened up by After-ANT as a springboard towards a second step of perhaps even greater critical-performative potential, inspired by recent developments in ANT-related STS, such as the work of Marres (2013) and de la Bellacasa (2012). This entails a shift from empirical and deconstructive studies of object organization, with their often elegantly implicit political critique, to a more straightforward generation of concrete and specific alternative trajectories towards the future by way of ontological experimentation. We appropriate this expression from Marres (2013) to conceptualize a move away from uncovering and criticizing that which is, thereby demonstrating that this could also theoretically be otherwise, towards a more practical hands-on exploration and experimentation with what could become through speculative practices of "making-otherwise." ${ }^{1}$

\footnotetext{
${ }^{1}$ We choose to use the somewhat strong expression "appropriation" instead of similar or related tropes such as "application" or "translation" to denote that our use of the concept diverges from Marres' specific definition of "experimental ontology," which is the exact wording she uses in her article (Marres, 2013). Our way of working with the concept is in no way irreconcilable or incompatible with Marres', but the errands are tangentially different. Whereas Marres uses the concept to highlight the relationally constituted normative variability of "objects" (in themselves understood, in turn, as relationally constituted entities), i.e., to highlight how specific "non-humans" can be variably invested or articulated with highly divergent ethical capacities and valences, we instead use the concept to highlight the potential for actively contributing to the ontological redefinition of specific "objects," and the normative affordances offered by such a practice. We also acknowledge that the practice which we here label as experimental ontology has strong affinities with what Deleuze \& Guattari (1994) define as constituting the practice of philosophy, albeit without being completely analogous to this (particularly with regards to questions of specificity and the level of inclination towards concrete empirical work). Nevertheless, it is interesting to keep in mind that Annemarie Mol, one of the most influential After-ANT scholars, has repeatedly referred to her research practice as "empirical philosophy", but then with a nod to the work of Lolle Nauta (see e.g. Mol, 1994; 2002).
} 
The staging of such ontological experiments would potentially be helpful in a realignment of critical management and organizational studies, away from just describing or criticizing actualities towards a generative exploration of potentialities, as also suggested by Spicer et al. (2009:550). In practice this can for instance take place through the formulation of suggested potential reconceptualizations of previously taken-for-granted objects; posing, in some concreteness and specificity, the question "what comes into the world that way, whether one chooses to throw in one's lot with it or not" (Haraway, 2013). Such a practice would aim at interfering politically by way of "performatively... interwoven description-and-normative-intervention located in more or less specific circumstances" (Law, 2009a:3) and would hence mark a shift in critical scholarly practice, by transforming matters of (scholarly) concern into matters of care and engagement through the production of "visions that 'cut' differently the shape of a thing... not only detecting what is there, what is given in the thing we are studying, but also to think about what is not included in it and about what this thing could become for instance if other participants were gathered by/in it" (de la Bellacasa, 2011:96). Experimental ontology in such a guise would amount to "an experimental practice like physics" but which "experiments on language, that is, it devises concepts that will have no meaning unless they succeed in bringing to existence those dimensions of experience that usual statements can ignore" (Stengers, 2011: 248). Further, it would be broadly 'pragmatist', in the sense of David Lapoujade's definition of this term, as denoting a "method of experimentation, or construction for new truth" according to which "A true idea, in the pragmatic sense, is an idea that changes something in a satisfactory way in the mind of the person thinking it." (Quoted in Stengers, 2011:251) The task of such scholarship would therefore be "to criticize, perhaps, but to transform critique into an instrument of modification" (Stengers, 2011:507).

To be able to concretize what we mean practically by the above we will in the remainder of this paper focus on investigating two "very big things" (cf. Jacobs , 2006) of "territorial sorts" (Kärrholm, 2013), which are generally considered to be of very different object kinds: a mine, Zinkgruvan, and a landfill, Gärstad Deponi. They are both located in southern Sweden, only about 75 kilometers apart. But even though they are close to each other and currently both substantially in the business of handling metals, they are to some degree also worlds apart. Why is this so? The short answer is: because, generally (at least in the "Western world"), mines and landfills are seen as each other's diametrical opposite: the first most often understood as a "virgin" natural resource, the start of a value chain, the latter as expedited waste, a culturally generated problem and nuisance. But are they necessarily really so different from each other? And what risks are there in assuming these differences as given and mutually exclusive?

The task we set before ourselves in this paper in relation to these two diverging "objects," is to unfold the practices that contributed to constituting and stabilizing them as particular types of objects, thereby showing how objectifying practices that wittingly and unwittingly organize or enact objects as objects, in effect can be conceptualized as contributing to the generation of an ontological shorthand in the form of "placeholders" (Latour, 2005) that cut out and fold an extensive set of relations into a (seemingly) coherent and (temporarily) stabilized whole. Such placeholders stabilize social worlds, for good and for bad. Fortunately, our argument goes, when sensed to be "for bad" for some reason or other, scholarly practice in an After-ANT vein may actually contribute to generating alternatives in the form of other potential ways to go about things. To make this point, we will take the reader on a journey exploring the variegated sets of practices that enact a mine as a mine and a landfill as a landfill, with the hope that our narrative will show how the aforementioned seemingly clear-cut distinctions between these different types of objects might not be so obvious after all, finally landing in the conclusion that what actually differentiates mines from landfills might have very little to do with the "objects in themselves," but much more so with the relational ecologies of practices of which they are part. 
The two reasons why we feel that the telling of such a story is of particular importance right here, right now, is on the one hand an engagement in the concrete issues at hand - the currently dominant objectification of mines and landfills, which we find deeply problematic, and on the other hand a caring for and interest in tinkering with After-ANT research approaches so as to explore their capacity to generate critical performativity. Finally, a third concern, or perhaps even meta-concern, that we want to address through our engagement with these questions and issues relates to the recent emergence of so-called Object-Oriented Philosophy (OOP) as a source of inspiration for organizational studies (for example Humphries \& Smith, 2014; Pierides \& Woodman, 2012). From our way of approaching things, we find many of the carrying metaphysical ideas underpinning this approach, and the consequences that come with them, deeply troubling. In our conclusions, we will therefore try to clearly articulate the contrasts between the thinking behind the approach we suggest and how this contrasts with OOP - as well as spelling out what we think is at stake in this difference with regards to the practice of social science (including but not limited to organizational studies).

To be able to make these last points we will in our concluding discussion also venture to situate our own manner of After-ANT-inspired ontological experimentation within a wider thought-landscape by suggesting that it is helpful to think of it as an empirically inclined research practice within a broader pragmatist tradition crucially concerned with 'how we abstract', and which treats objectifying practices as central elements of this. This philosophical tradition recognizes that any act of abstraction constitutes at one and the same time a reductive as well as creative process (Stengers, 2011; Law 2004) which can generate new 'holds' or 'handles' on the world, thereby opening up for the reconfiguration of related practices and institutions. Within such a context, that hence places the importance of ontological experimentation center-stage, After-ANT work, and perhaps particularly the practices of topology mapping worked with in this paper, can be seen as concrete methodological devices that can be of help in engendering novel ways of articulating a specific problem at a particular time and place, thus generating Critical Performativity in the process.

\section{Unfolding objects: engendering object experiments through topology mapping}

To be able to discuss the issues at hand in a less esoterically philosophical manner, we first need to return to our story about the Zinkgruvan mine and Gärstad landfill. There are of course innumerable ways to construct such a narrative. But as previously intimated, we choose a specific way of going about this, inspired by After-ANT scholarship. We do so because we want to show that far from being empty critical gestures or theoretical navel-gazing, investigations in this vein can function as situated tools for "working in and upon particular analytical and political problems in order to know these better and to move them on" (Law, 2009a:9), thus constituting a valuable resource for organizational studies that aims at "crafting and creating social change through the committed practice of performative research" (Spicer et al., 2009:555). As Alcadipani \& Hassard (2010) have already argued before us, After-ANT is perhaps particularly suited for this type of work because there is a hunch nestled into it that if we mess around with any taken-for-granted object long and carefully enough we will come to find that it will unravel before us as an uneasily and temporarily stabilized comingtogether of many heterogeneous components.

Based on such an intuition, Mol and Law (1994) and later Law and Singleton (2005) turned towards studying how objects are stabilized, taking a particular interest in how "a certain shape [can] maintain its form even though some properties are changing" (Law, 2002a:94). In related publications, it is proposed that objects may gainfully be studied in their regional, network, fluid and fire topologies. The first of these topological registers traces objects as they are enacted "with common sense" (Law and Singleton, 2005), where the objects hold a tangible physicality within a given position in Euclidian space. The world is rendered apprehensible in the form of mutually exclusive patches of territory, the constitution of which is conceptualized to be so coherent and 
stable that their external borders cut them cleanly off from other objects and processes in both Euclidian and conceptual space, as when states on political maps are portrayed by their borders and an indiscriminately colored surface inside of these. Around the physical entity, however, the second topological register, that of heterogeneous network, maintains the shape of the object. Here, proximity is not an expression of physical distance but how the parts are relationally linked. For example, when we turn on the domestic central heating, not only a physical unit is started but an entire socio-technical network in the form of water flowing from the ground, market structures, ownership, expert discourses and much more (Callon, 2002). Mapping an object in its network topology, the type of research that 'classic' ANT has become so famous for, thus demands paying careful attention to the manifest sets of heterogeneous relations that the object depends upon for its existence, even when these stretch beyond what is generally considered to be the boundaries of the object in question. ).

In order to challenge the dominance of work tracing the above two topological registers in contemporary social science, Mol and Law (1994) suggest a third relevant register - that of fluidity in which object stability depends on the capacity to be slippery, to flow, to leak or to meander. One example is de Laet and Mol's (2000) bush pump, which admittedly retained its function - to produce clean water - through innumerable translations and transformations, as the design and physical as well as institutional make-up varied depending on local needs and desires. A mapping of an object in a fluid topology hence implies paying careful attention to when, what is referred to as a distinct 'object' comes to mutate in various aspects as it travels in time and space, but nevertheless can be claimed to hold a degree of integrity throughout these changes. Law and Singleton (2005) do not stop there, but suggest a fourth important topology for object investigations, fire. When studied in this topology, more elusive relations outside the more readily traceable network of the object are also investigated so as to tease out how they may be producing effects vital for the stability of the object (Moreria, 2004). This assumption is based on the notion of stability as an outcome of the relationships between the present and absent. Law (2002b), for instance showed how the development of an aircraft wing was driven by the Russian threat during the Cold War, a threat that was invisible in the formalism underpinning the suggested design, but nonetheless vital for its actualization. A mapping of an object in its fire topology thus pushes the inquirer to pay attention to the heterogeneous ecology or "hinterland" (Law, 2004) of an enacted object; what needs to be manifestly present and absent for the object to exist in its current form - but also trying to figure out what needs to be implicitly present/absent, even if it is not immediately and directly evident at a given instance or by just focusing research on the object in question or its manifest relations.

Approaching taken-for-granted objects through mapping them in the multiple topological registers suggested by After-ANT scholarship thus helps us conceptualize them as being neither self-contained nor self-sufficient, but rather always enacted and sustained in webs of relations not only within but also outside (in a topological as well as topographical sense) of the seemingly coherent object or thing. This way of analyzing objects thus both highlights the importance of the variegated sets of practices that function to maintain the object as object, but also at the same time points towards the relevance of context for defining objects, but doing so in a manner that does not assume any form of stability in that context, instead defining "context" as all those relations that bear down on a situation or site but which are not directly recognized as ontologically constituting a part of it (see also Asdal \& Moser, 2012).

\section{Enactment 1: Mine and landfill as common-sense regional objects}

Mol and Law's first stop in the topological analysis focuses on the common-sense spatial definition of an object, where each object is seen as having a distinct and exclusionary place in Euclidean space. Such "regional" objects are thus enacted as uniform and straightforward, with clear-cut boundaries that clearly delimit them from the "outer world" and other objects. In the regional, common-sense 
register, both Zinkgruvan ("the Zink mine") and Gärstad deponi ("Gärstad landfill") are articulated as specific kinds of objects already in their proper names: the first a mine and the second a landfill. And consequently, from a regional logic, the first supposedly being a place where "mining things" go on and the second a place where "landfilling things" go on. In Euclidean space, mines are a rare phenomenon and occur only in certain countries (BGS , 2013), where they cover relatively small areas of land, e.g. $0.5 \%$ of the Swedish surface. Even if an increasing number of mines are currently being projected in Sweden (supposedly the most beneficial place in the world to open a new mine according to the Fraser Institute, 2014), there are presently only three mines in operation in southern Sweden, of which Zinkgruvan is the southernmost and largest. Unlike mines, landfills are, however, becoming fewer and increasingly closed in Sweden. Landfills have historically been a fairly common occurrence, where previously virtually every village had one of its own. Sweden alone there are over 4000 (Frändegård et al., 2013). Nevertheless, more than $70 \%$ of all Swedish landfills that were in operation in 1994 have today been capped (ASWM, 2008). One of the few landfills that is still open in Sweden is located in Linköping: Gärstad Landfill.

Zinkgruvan has a well-defined location on the map, and can be reached by unpaved roads deep in the forest between Örebro and Linköping, about $250 \mathrm{~km}$ southwest of Stockholm. Gärstad Landfill is also clearly indicated on the map on the outskirts of Linköping, less than 75 kilometers, or an hour's drive, from Zinkgruvan, and adjacent to the E4, Sweden's major transport artery. A spontaneous visitor to any of these sites will soon discover that the mine and the landfill are not only clearly delineated on the map directing them there, but that the boundaries of the objects on the maps are concretely manifested in the landscape by way of barbed-wire fences that clearly demarcate the external borders of Zinkgruvan and Gärstad Landfill. The exclusionary function of the fences makes both the landfill and the mine inaccessible to outsiders. But by standing outside the fence and looking in, while keeping in mind the meaning of their names, the Zinc mine (Zinkgruvan) and Gärstad landfill, we understand that mining things and landfill things are ongoing in these places. For example, on any given workday, the gate of Zinkgruvan opens for empty trucks, leaving the area bursting with chiseled metal resources. This is also completely in line with the standard definition of a "mine" according to Merriam-Webster dictionary (2014), "a pit or excavation in the Earth from which mineral substances are taken." In many ways, a mine such as Zinkgruvan thus seems to be something manifestly present and presence-making through its designated role as the starting point in a materializing resource flow - a resource site in which metals hidden away in the Earth's crust are brought up, refined into resources and sent into the economy. The valuable is separated from the less valuable in a process that Mumford (1934) held as the basis for the capitalistic notion of value: the separation of rarity from the ordinary.

A landfill is in many ways commonsensically understood as the opposite of a mine. To begin with, from a topographical perspective, one is a growing void while the other grows in height. In spite of a height of $25 \mathrm{~m}$, Gärstad landfill is difficult to get a glimpse of. If you travel along the E4 highway a large incineration plant, which has become a sort of landmark for travelers through Sweden visible several kilometers ahead, obscures the entire landfill. Even when approaching the entrance to the landfill, it is still difficult to see the actual landfill due to the surrounding culverts with tall trees. The difficulties of spotting the landfill, even through the fence, reveal that the ongoing activity is kept apart. The gates open only when trucks overflowing with waste enter the site, and then again when they leave empty. So far, this is again in line with standard dictionary definitions, for according to Merriam-Webster (2014) "landfill" is the name by which we know "an area where waste is buried under the ground." Thus, the landfill functions as a waste site of manifest absence-making, the end station for mass consumption where what once were resources are abandoned, hidden and forgotten "out of sight, out of mind" 2 (see further Zapata Campos, 2013), or as Hetherington (2004)

\footnotetext{
${ }^{2}$ Nevertheless, compounds often leak from abandoned landfills and contaminate the local environment thereby again becoming manifestly present to humans again.
} 
comments: "disposal is about placing absences." Landfills are commonly, and also in this case, perceived in a regional definition as unfortunate phenomena; end stations, hidden away, nonresource and hazardous and which, according to European (European Council, 1999) as well as national regulation (SCS, 2001), should be closed down as quickly as possible. Hence, enacted in their regional topography, the landfill and the mine seem to be each other's antithesis, or plainly put: each other's Other. One of them is a growing void in the Earth's crust, a prosperous place, a material starting point where metals are brought into the economy. The other is a growing pile, a valueless place, a material end station where metals and other material are abandoned and de-economized, as seen in Figure 1.
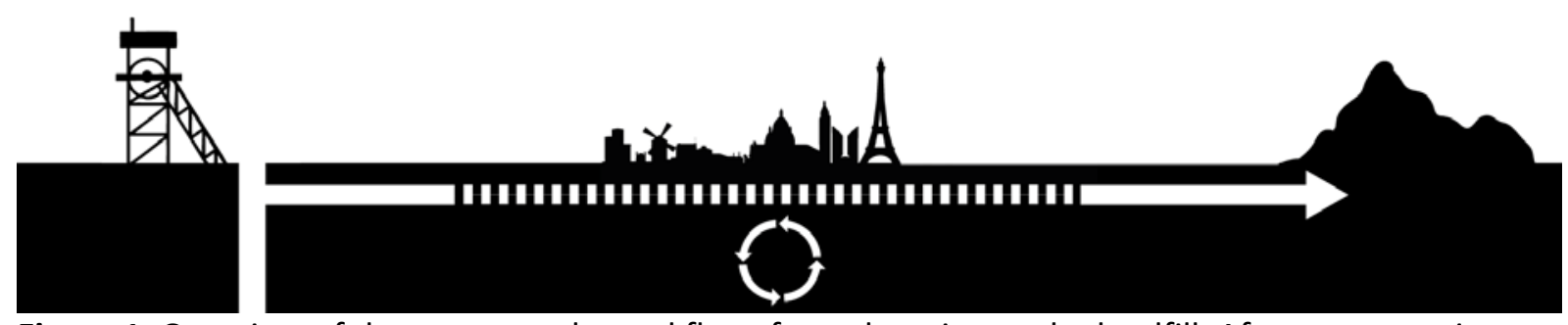

Figure 1. Overview of the conceptual metal flow: from the mine to the landfill. After consumption metals can be recycled/reused, but are rarely re-circulated more than two or three times before ending up at a landfill (Matsuno et al., 2007).

So far we have been looking at the mine and the landfill from a distance. So it is time to find out what is actually going on in these well-defined places, through both literally and symbolically opening up the gates to these places. By following students on field trips, attending so-called "landfill safaris," being lowered into the mine shaft one kilometer inside the planet, interviewing employees, studying permits, staff magazines and commemorative books, we have tried to understand more about the practices that enact a mine into a mine-object and a landfill into a landfill-object.

\section{Enactment 2: As networks of manifest relations}

In the next topological register to be investigated, objects are not mapped as a singular point in Euclidean space, but are instead understood to be the outcome of networked relations and processes. In such an analysis, various non-human as well as human elements assemble into a network, forming the object and holding it in shape. Previously, for example, Hudson (2001) has convincingly argued that mines are not only a material outcome, but the result of political and economic work, while Myra Hird (2013) demonstrated how landfills have become risky objects through the interaction between micro-organisms and human debris. In this part of the paper, however, we are more interested in how human and non-human elements have come together to practically shape and maintain Zinkgruvan as a mine-object and Gärstad landfill as a landfill-object.

If you are welcomed on an organized study visit to Zinkgruvan you will be invited on a long elevator ride down one of the two mineshafts, while the guide most probably in the meantime will be telling you that Zinkgruvan opened in the year 1857 after the Belgian mining company Vielle Montage purchased the concession rights to the area. The start of a mine at this particular spot was not a coincidence. For example, the proximity to Lake Vättern enabled water connections to Belgium and thus a cheap means of transportation, which reduced costs and helped realize the project. Many mines had just been closed in the area, which made an experienced local workforce available and contributed to local goodwill towards the project. As evinced above, in addition to intentional human organizing ambitions and investments, Zinkgruvan's historical becoming also depended upon many non-human key elements that have made a crucial difference. One such element which is perhaps 
particularly central is the geological process that has been beyond the scope and reach of human designs: the actual mineralization, i.e., the concentration of metals at this location. Two billion years ago the landscape of Zinkgruvan consisted of sea, mountains and volcanoes. Water heated up by volcanism containing acids was circulating deep inside the mountains. The warm, acid water dissolved metals and then flowed into the cold ocean through cracks in the mountains. In the meeting between cold and warm the fluids containing metals cooled down and metals were precipitated as sulfides in layers on the seafloor. The stillness of the water prevented the spread of metals over large areas (Gunnarsson and Gunnarsson, 2007: 9).

So thanks to the coming together of these events at this location, in the mid-1800s a Belgian mining company started to build an industrial community from scratch surrounding their new investment. Although Zinkgruvan has been active for over 150 years large amounts of minerals are still left in two distinct ore bodies: the zinc ore and the recently prospected copper ore, which according to the owners Lundin Mining (2012a) will continue to be a profitable deposit for at least another decade. All mineral categories combined, i.e., both profitable today and assumed in the future, add up to approximately $2,800,000$ tonnes zinc (9.2\%), 1,300,000 tonnes lead (4.4\%) and 230,000 tonnes copper (2.2\%) (Lundin Mining, 2012a), as seen in Table 1.

Table 1. Overview of the metals amounts in Zinkgruvan, presented according to its two main ores, including profitable reserves as well as assumed resources of metals (Lundin Mining, 2012a).

\begin{tabular}{|l|c|c|c|c|}
\hline \multirow{2}{*}{} & \multicolumn{2}{|c|}{ Copper ore } & \multicolumn{2}{c|}{ Zinc ore } \\
\cline { 2 - 5 } & Amount (tonne) & Rate (\%) & Amount (tonne) & Rate (\%) \\
\hline Total Ore & $10,510,000$ & & $30,000,000$ & \\
\hline Copper & 230,000 & 2.2 & & \\
\hline Zinc & 40,000 & 0.4 & $2,800,000$ & 9.2 \\
\hline Lead & & & $1,300,000$ & 4.4 \\
\hline Silver & 340 & 0.0032 & 2,580 & 0.0086 \\
\hline
\end{tabular}

Today, Zinkgruvan is in many ways a typical start in a resource production process. The loosened chunks of ore reach the surface through a ramp and enter one of the two enrichment plants on site, where it is first crushed into smaller parts. Then metals are separated by flotation from each other and the waste rock. Concentrates are trucked from the mill to the inland port of Otterbäcken on Lake Vänern from whence they are shipped via canal and sea to European smelters. At the smelter, silver can be separated from the lead. In 2011, about 110,000 tonnes of metals (zinc, copper, lead and silver) were extracted from Zinkgruvan (Lundin Mining, 2012b).

Turning to the landfill - the opening of the landfill, just like the mine, included an active intentional decision by humans, but was nevertheless dependent on a whole range of other elements coming together such as finance, geology, technology and law at this specific location. In the early 1970s, the former municipal landfill of Linköping, Kallerstad landfill, started to reach its limits, which forced the municipality to look for alternative locations for a new landfill. A number of alternative locations were suggested to the Swedish EPA (SEPA, 1973). However, the final choice, Gärstad, depended on several favorable circumstances converging to produce a specific human judgment of appropriateness and desirability. The place was a few kilometers outside the city, an old industrial site with few local residents. Geology played a crucial role here too, since the ground of the location was of favorable geological clay, preventing leachate.

Permission for deposition was granted by the Swedish EPA in 1973 (SEPA, 1973). Initially various types of waste were deposited, including construction and demolition, soil, industrial and household waste. However, in line with higher oil prices due to the energy crises of the 1970s, Linköping municipality decided to reduce the dependence on oil and increase the use of waste as fuel 
(Lundberg, 1984: 36-39). To increase the capacity, the old waste incinerator downtown was closed in 1980 and a new waste incineration plant was built next to Gärstad landfill. By sending most waste to incineration, the materiality of waste changed considerably, as mainly ashes remained for disposal.

Today, waste containing metals and other discarded materials reaches Gärstad landfill by trucks from over thirty municipalities in the surrounding region. In addition, $22 \%$ of the waste handled at the site is shipped in from neighboring countries in Europe such as Norway, Germany and Great Britain (Tekniska Verken, 2013: 16). Hence, given the global outflow from Zinkgruvan and inflow to Gärstad - even though they are topographically close in Euclidean space, they are part of very different networks, and therefore it is generally not the same mineral molecules that leave Zinkgruvan which then end up in Gärstad, despite their apparent proximity to each other. The household waste reaching Gärstad is sent to incineration. Electricity and heat is extracted from the combustion process while the waste volume is reduced by $75 \%$ in weight. The remains consist of the incombustible minerals from the fuel. Besides waste ashes, construction and demolition waste and metal hydroxide sludge are also sent to Gärstad. In 2011, 140,000 tonnes ${ }^{3}$ of waste was in one way or another sent to the landfill (Tekniska Verken, 2012: 33).

Mapped in their network-relational topology, it becomes apparent how the landfill and the mine have evolved through the spatiotemporally distributed convergences of humans as well as nonhumans, but into distinctly different objects. One as a resource site, which normally pushes metals to whoever pays most to receive it, while the other has assembled into a waste site, which pulls metals and other material from whoever pays most to get rid of them. These two networks are furtheragain, studied in their network topology - farther apart than one might expect considering their Euclidean proximity and thematic relation. The reason for this is that they are simply inserted not only in different ways, the one as a starting point and the other as a finish in resource flows, but also in different sets of network relations - any flow of metal between them constituting a mere coincidence.

\section{Enactment 3: as fluids that meander and mix}

When regional as well as network-relational enactments of objects such as a mine and a landfill are compared, differences easily emerge, and the particular characteristics of the objects are emphasized, chiseled and allowed to frame the description of the objects. On the contrary, in mapping objects in their fluid topologies we instead take an interest in how they may persist and hold some degree of integrity as objects through acting "as fluids that gently reshape their configurations" (Law \& Singleton, 2005:348). Further, when we begin to look at Gärstad and Zinkgruvan together in their fluid topologies, by focusing on the practices that enact the objects, the differences are sent to the background, edges begin to blur, and leaks between these two previously so clearly differentiated types of objects instead come to the forefront. For instance, we quickly begin to see that Gärstad landfill becomes not only an end station, but manifestly also a starting point in the resource flow.

To begin with, recycling of metals flowing into Gärstad landfill site has now been ongoing for more than a decade. In the waste management process large, visible pieces of metal are as thoroughly as technically possible extracted from incoming waste masses, such as construction and demolition waste, and sold to the recycling industry. Metals in the waste ashes are also recovered at the site. After incineration, the ashes are stored a few months on the landfill. The ashes are then pushed through a crusher, which releases tightly bound metals, in this way enhancing their recyclability. Since the year 2001, ferrous metal is separated from bottom ash with the help of a magnet before the ash residues are disposed. In 2006, eddy current was added to separate out aluminum, copper,

\footnotetext{
${ }^{3}$ Including masses used as construction materials at the landfill site, see further below.
} 
zinc and brass. In sum, 8,500 tonnes of metals (primarily iron, copper, aluminum and zinc), as seen in Figure 2, were recovered from the waste reaching Gärstad during 2011 (Tekniska Verken, 2012: 33), corresponding to $6 \%$ of the deposited waste $(140,000$ tonnes).

Before the large-scale introduction of metal recycling, more or less all the incoming waste at Gärstad was directly landfilled. ${ }^{4}$ These disposal practices have over time accumulated metals in the landfill. Similar to the accumulation of metals in the Earth's crust, the accumulation of metals in a landfill occurred beyond human intention and control, not to generate a resource base, but to deposit, hide and forget items the owner wants to get rid of. But unintentionally these deposits have in accumulation at one place - the landfill - produced the emergent geological properties of a resource base. In a material flow analysis Tanha and Zarate (2012) have estimated that there is 4 million tonnes of waste ${ }^{5}$ with up to $9 \%$ metals in Gärstad landfill; of which 180,000 tonnes (4.5\%) ferrous metal and similar amounts of non-ferrous metals, e.g. 111,000 tonnes (2.8\%) of aluminum, 27,000 tonnes $(0.7 \%)$ of zinc, 9,000 tonnes $(0.2 \%)$ of copper, as seen in Table 2 .

Table 2. Overview of the metal amounts in Gärstad landfill (Tanha and Zarate, 2012). The result is presented in uncertainty ranges (Min and Max), correlating to the metal variation in samples at Gärstad.

\begin{tabular}{|c|c|c|c|c|}
\hline & \multicolumn{2}{|c|}{ Amount (tonne) } & \multicolumn{2}{|c|}{ Rate (\%) } \\
\hline & Min & Max & Min & Max \\
\hline Total waste & \multicolumn{2}{|c|}{$4,000,000$} & \multicolumn{2}{|c|}{100} \\
\hline Iron & 127,000 & 180,000 & 3,2 & 4,5 \\
\hline Aluminium & 98,000 & 111,000 & 2,5 & 2,8 \\
\hline Copper & 7,000 & 9,000 & 0,2 & 0,2 \\
\hline Zinc & 16,000 & 27,000 & 0,4 & 0,7 \\
\hline Lead $^{A}$ & 2,000 & 5,000 & 0.05 & 0.1 \\
\hline Titanium $^{A}$ & 8,000 & 10,000 & 0.2 & 0.3 \\
\hline $\operatorname{Tin}^{A}$ & 500 & 1,000 & 0.01 & 0.02 \\
\hline Others & 12,000 & 18,000 & 0.3 & 0.5 \\
\hline
\end{tabular}

A Amount in ashes only

However, specifically in the case of forming metal deposits, non-human elements commonly grouped under the label "nature" do seem to be a somewhat more potent geological force than humans (although the comparison might not be entirely telling, considering that the natural geological process had a few more million years to reach its result). The amount of specific metals such as zinc, copper and lead is significantly greater in Zinkgruvan than in Gärstad. For example, Gärstad landfill contains around 8,000 tonnes of copper while Zinkgruvan holds over 200,000 tonnes. But bear in mind, the total volume of Zinkgruvan is 10 times greater. If metal concentrations instead are compared between a mine and a landfill, they sometimes appear to be comparable. In the case of Gärstad landfill the copper concentration is, however, not comparable with Zinkgruvan, but it is comparable with the copper concentrations of other active copper mines such as Aitik in northern Sweden (cf. Bernander, 2012). On the other hand, other metal concentrations in Gärstad landfill, e.g. for iron, are comparable to general levels in the Earth's crust (5-6\%).

\footnotetext{
${ }^{4}$ Note that we write "large-scale introduction" and "more or less." Small-scale informal recycling had always existed at the site. In consecutive rounds waste collectors, landfill employees and private citizens informally extracted metals from the waste piles and sold them on the black market to scrap yards. Today these practices are discontinued as Tekniska Verken, the owner of the landfill, over time has realized the value of the incoming garbage, making informal recycling a direct violation of company policy.

${ }^{5}$ Including ashes used as construction materials at the landfill site, see further below.
} 
To be scrupulous, the same qualification about being both a starting-point and end-point in resource flows also has to be made with regards to Zinkgruvan, with the difference that the dual role of the site is perhaps not as readily identifiable as in the case of Gärstad. Since the extracted ore contains about $8 \%$ zinc, $4 \%$ lead and 2\% copper (Lundin Mining, 2012b), large amounts of waste are created during the enrichment process when the metal is separated from the rest of the rock, which then becomes enacted as waste rock in need of disposal. In 2011, 1,000,000 tonnes of waste from Zinkgruvan was disposed in one way or the other (Lundin Mining 2012b). In addition, 450,000 tonnes of waste in the form of overburden, i.e., uneconomical material above the ore body, was also generated (SGU, 2012a: 31). In total, around 1.5 million tonnes of waste was produced in Zinkgruvan during 2011, partly ending up in a pond a few kilometers from the mine.

Thus, the 110,000 tonnes of metals recovered from Zinkgruvan correspond to about 7-8 \% of the waste in need of deposition. The proportion between metal recovery and deposited waste appears quite similar for the landfill (6\%) and the mine (7-8\%). The scale for recovery and deposition is however different between the mine and the landfill: 13 times more metals and 10 times more waste are recovered and disposed, respectively, at the mine. However, the proportion can differ greatly between different mines. An iron mine needs high concentrations to be profitable, for example proportions of $60 \%$ commodity and $40 \%$ waste is extracted from the Swedish iron mine Kiirunavaara (LKAB, 2013). On the other hand, a copper mine can be profitable at very low concentrations, for example normally $0.2 \%$ commodity and $99.8 \%$ waste is extracted from the Swedish copper mine Aitik (Bernander, 2012).

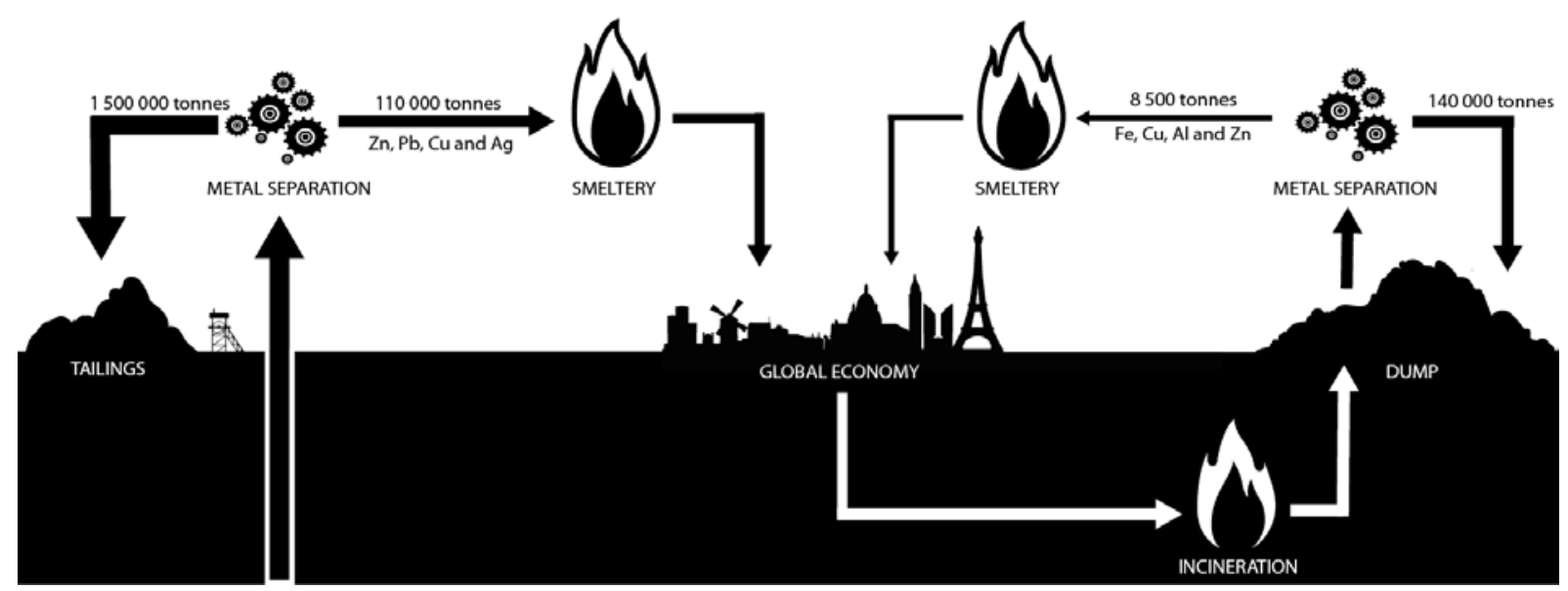

Figure 2. An overview of the material flow into and out of Zinkgruvan and Gärstad landfill. Both sites appear to be starting points and end stations in the material flow chart. Please note that although Zinkgruvan and Gärstad landfill are close in Euclidean space, they are not directly part of the same relational network, since the outflow from the mine as well as the inflow to the landfill are globally dispersed, making any direct flow between them a mere coincidence.

The notion that resources are not only flowing on top of Gärstad landfill, on the site, but are also buried inside the landfill has been explored by Tekniska Verken, the owner of the landfill. Recently, they have experimented with novel ways of productively utilizing disposed waste. For example, ashes have been excavated to be used as construction material and to stabilize the base of landfill cells. Pilot studies, during the early 2000s, investigated the possibilities to extract metals from deposited ash. In these cases, Tekniska Verken through their contractor exhumed and separated waste, which dates from the time before metals were separated. After all, the thinking goes, separating metals from ashes that have been stockpiled for a few months, which is the case today, cannot differ that much from separating metals from ashes disposed a few years ago. However, the pilot studies 
stopped since the mechanical separation process adapted to fresh ashes proved less suitable to extract metals from the old ash with its solid bonds between materials strengthened over time ${ }^{6}$.

With such novel recycling initiatives of material previously deemed as waste in mind, we can turn to re-examine the old waste heaps of Zinkgruvan at Lake Vättern, which consisted of mining residues, i.e., tailings which resulted from the traditional use of gravity as a method to separate metals from the waste rock. Gravitation generally worked quite well to separate lead from rock - but worse for zinc, since its weight was near that of rock. Hence, large quantities of waste containing $5-13 \%$ zinc were in the past pumped out into Lake Vättern. In 1931 flotation began to be used in Zinkgruvan to extract the ore more effectively. With the introduction of flotation, the old tailings which had amassed since the 1860s into a dune landscape along the shore of Vättern suddenly became interesting as a potential resource base. After 70 years of ineffective enrichment technology, the introduction of flotation transformed this waste landfill back into a zinc mine. Between 1937 and 1967 over 1 million tonnes of old tailings were reprocessed (Gunnarsson and Gunnarsson, 2007: 4142). The zinc mine became a landfill, which became a zinc mine. Hence, in both cases, Zinkgruvan and Gärstad, the landfill became a mine, waste became resources, the material flow turned and an end station became a starting point. So for a long time, in both of the sites, resource-making has implied waste-making and waste-making has generated affordances for resource-making.

Analyzed in their fluid topology in the way we have been, mines and landfills in many aspects do appear to blend into each other as object types. So upon closer scrutiny, the constitution of a starting point and end point in a material flow appears to be less clear than is usually imagined, with wastemaking and resource-making taking place in variegated intertwined loops in both the mine site and the landfill site, forming a sequence of events (see also Heatherington, 2004:161). Although Zinkgruvan and Gärstad landfill were assembled for different purposes, the one to be a resource site and the other a waste site, the cases show how the deep entanglements between resource-making mining practices and waste-disposing landfill practices make the landfill-as-object and the mine-asobject easily slip into and blur each other. But the blurring of boundaries does not only pertain to the "social" activities performed at the sites, but also to the "material" constitution of the sites. For instance, the landfill Gärstad contains a concentration of copper equivalent to that of active copper mines, and this is further not unusual (see also Alm et al., 2006; Karlsson and Åslund, 2014; Wagner and Raymond, 2015). Additionally, even if the concentrations of metals in Gärstad landfill and Zinkgruvan proved to differentiate with regards to some presently mined metals, there are many landfills known to have much higher metal concentrations, for example the tailing pond of Zinkgruvan in Lake Vättern, which as a result of inefficient technologies had similar zinc grades as the presently mined "natural" ore body. Certainly, there are places above as well as below ground with high and low concentrations of various metals, some of which are currently celebrated as crucial resources while other are dismissed as meaningless, troublesome waste.

\section{Enactment 4: the flickering fires of absent-presences}

Mapped in their fluid topologies, the mine and the landfill do not appear fundamentally opposed to each other in some form of eternal order of the universe, and neither is a practice of resourcemaking, such as mining, and one of waste disposal, such as landfilling. Rather, they appear deeply entangled with each other without any radical alterity in between (see also Douglas, 1966). Nevertheless, differentiation between mines and landfills is persistent as demonstrated in the regional and network topology. At least within "Western" cultures, mines and landfills are simply not considered very similar. So cultural ideas do make a difference here, for instance drawing upon preconceptions about what constitutes resources, wealth and "natural kinds" on the one hand and

\footnotetext{
${ }^{6}$ There are nevertheless successful examples of large-scale extraction of metals from other ash landfills (e.g. Wagner and Raymond, 2015)
} 
waste, dirt and "artificial kinds" on the other hand, ascribing relative worth to sites associated with these categories. ${ }^{7}$ But at Zinkgruvan and Gärstad landfill, these ideas are not signposted or communicated in any direct way. Rather, they generally remain completely implicit, taken for granted or even subconscious. That is: they constitute what Law \& Mol (2001) label as absent presences, making a crucial difference to the constitution of the object - but without in themselves being directly or manifestly observable on-site.

Mapping this type of constituting relation amounts to studying objects in what Law/Mol/Singleton call their fire topologies, i.e., how objects are "generated in juxtaposition with realities that are necessarily absent, even though they bring versions of those realities to presence" (Law \& Singleton, 2005:345). Therefore, to map an object in its fire topology it becomes "necessary to go elsewhere... necessary to go to places that are absent" (Law \& Mol, 2001:617, emphasis in original). We might for instance learn something more about both Swedish mines and landfills in their fire topologies by traveling to the corridors of government ministries and the meeting rooms of parliamentary committees in Stockholm - the capital of Sweden and the site of Swedish government institutions. And further into the pages of the Swedish Code of Statutes, the official publication of Swedish laws and ordinances, as enacted by the Swedish Parliament and Government. Here we will find a very clear differentiation between mines and landfills as types of objects, and a legal and administrative differentiation that very much makes a difference.

For instance, in Sweden, mines are by law (SCS, 1998) defined as a "national interest." This means that a mining company does not need to buy land or ask for permission from a landowner to gain access to metal ore. A mining permission is usually granted by a court, even if the landowner raised objections against the exploration permit (SCS, 1998; SR, 2010). Hence the mining sector may actively prospect and extract metal deposits anywhere in the Earth's crust within the borders of Sweden. The mining industry does pay a mineral allowance for extracting ore licensed after the year 2005, consisting of $0.2 \%$ of the extracted minerals value, as seen in Figure 3 . Three-fourths of this money goes to the landowner and one-fourth to the state (SCS, 1991). For the year 2009, the mineral compensation was in total approximately $€ 22,500$ (SGU, 2011). However, a quarter of this small sum also indirectly feeds back into the mining sector, as the government adds its quarter of the mineral compensation to geological research (Swedish Government, 2004).

Considering these favorable institutional arrangements in Sweden, it is not surprising that mines are constantly opened up for exploitation, and more appear to be on the way ${ }^{8}$. The Swedish mineral strategy (Swedish Government, 2013), which guides Swedish metal policy, includes several new measures to expand the domestic mining sector through, among other things, facilitating the construction of dwellings in mining communities by changing the governmental guarantees, reducing the process time for mining permissions by increasing the grants to licensing authorities, investing $€ 400$ million in mining-related infrastructure and a further $€ 23$ million to research in the fields of mining, minerals and steel. Further, the government has vowed to use its influence and resources to promote the Swedish mining sector internationally.

Not only are targeted public investments made to support the expansion of the mining industry, but mining operations are also exempt from landfill tax, beneficiaries of carbon tax, energy tax and sulfur tax reductions - as well as complimentary services to prospectors. This governmental support is crucial for the feasibility of the Swedish mining industry. In 2010, the subsidies to the mining sector were estimated at approximately $€ 4$ billion, which was almost twice as high as the value added by

\footnotetext{
${ }^{7}$ A detailed investigation of the effects of cultural norms and values for the enactment of mines and landfills as different object types deserves closer scrutiny, but is unfortunately beyond the scope of the present study.

${ }^{8}$ In 2010, six mining concessions and 118 prospecting permits were granted by the Swedish mining inspectorate (SGU, 2012b).
} 
the same sector (Johansson et al., 2014). Given the huge amounts of waste generated by the mining sector every year ${ }^{9}$, the most beneficial of all these subsidies is the exemption from landfill tax, a tax of $€ 50$ for every tonne of disposed waste (SCS 1999:673). For example, considering the 1,500,000 million tonnes of waste disposed by Zinkgruvan in 2011, the exemption from landfill tax alone represented a revenue forgone subsidy of $€ 75$ million to Lundin Mining, the proprietors of Zinkgruvan.

None of the above supports or subsidies apply to the recycling of secondary metals at landfill sites. Instead, by being organized into the legal category of "landfill" rather than "mine," residues from metal separation sent for deposition at Gärstad is targeted full landfill tax, as seen in Figure 3. To avoid this financial penalty Gärstad owners Tekniska Verken, like many other landfill owners in Sweden, creatively use the waste ashes in various construction projects such as building roads and embankments on the landfill site, meaning that only small amounts of waste ash are formally deposited in the landfill and subject to tax. Further, rather than promoting extraction and recycling of metals from former landfills, national and European regulations (e.g. SCS, 2001; European Council, 1999) increasingly encourage the closing down, sealing and permanent capping of landfill sites. This contributes to making these places even more "out of sight, out of mind," even though they may contain higher concentrations of metals than in currently operating mines - which in turn are the subject of numerous subsidies that use public tax money to bolster the profitability of "virgin" ore mining operations. However, in contrast to the "Wild West"-style free-for-all on Swedish virgin ore, the metals in a landfill are the exclusive property of the landfill owner. Several convictions of waste pickers have demonstrated that taking metals from a landfill without the owner's permission, although they are not fulfilling any function (but perhaps leaking), is a punishable crime. In contrast, the mining sector does not need to buy land or ask for permission from any landowners to gain access to metal ore.

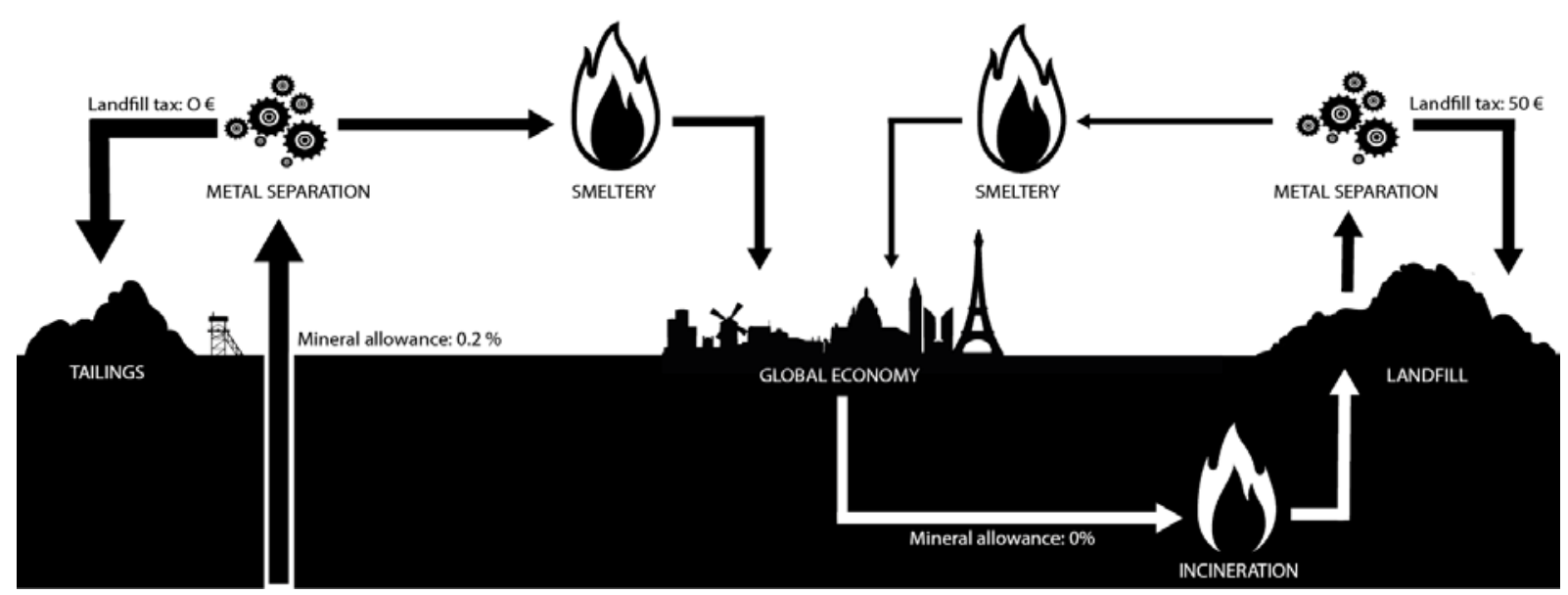

Figure 3. An overview of the conditions for resource extraction at mining sites, the starting point and at landfill sites, the end station of the material flow chart.

The effects of being codified and enacted as a "national interest," like mines, rather than as a "local nuisance," like landfills, also generate other, sometimes quite elusive consequences. For example, almost all charges against mines for violating environmental permits are dismissed without further action (Müller, 2013). During the 2000s, Zinkgruvan was prosecuted four times for violating its environmental permit when, for example, diesel was emitted into the environment. None of these charges have led to convictions according the local authority (Nilsson, 2014). The reason why mining companies are rarely convicted in court for environmental pollution is that the legally codified

\footnotetext{
${ }^{9}$ In 2010, 89 million tonnes of metal mining waste was generated (SEPA, 2012), corresponding to $75 \%$ of all waste generated in Sweden during 2010.
} 
pollution levels are in the form of "guidelines" rather than absolute limits. In addition, the guidelines for various environmental emissions are different for a landfill such as Gärstad, generally conceptualized as a nuisance, and a mine such as Zinkgruvan, generally conceptualized as a resource. According to Gärstad's environmental permit a maximum of $5 \mu \mathrm{g}$ lead, $1 \mu \mathrm{g}$ cadmium and $50 \mu \mathrm{g}$ zinc per liter of water are allowed to discharge into the recipient (Gummesson, 2014), while Zinkgruvan's environmental permit allows higher levels: a maximum of $75 \mu \mathrm{g}$ lead, $0.5 \mu \mathrm{g}$ cadmium and $500 \mu \mathrm{g}$ zinc per liter of water discharging into the recipient (Nilsson, 2014).

There are many different types of absent-present relations and heterogeneous practices that generate and sustain Zinkgruvan and Gärstad as objects of different types. Here we have chosen to focus on the ordering practices employed by the national government of Sweden that institutionally enacts the mine and the landfill as being of different societal value or worth - where the mine is assigned a value deserving of public subsidy, the other devalued, worthy of public penalties.

The background to the institutional differentiation of the landfill and the mine can also, if one so likes, be traced to even wider networks with an authority to continuously sustain the divergent conditions for the extraction of these two metal stocks. In Sweden, mines have traditionally been a matter of economic growth and regarded as a backbone of the Swedish economy (Swedish Government, 2013). Hence, a regulatory structure consisting of the Geological Survey of Sweden and the Mining Inspectorate, both operating under the auspices of the Ministry of Industry, are responsible to formulate and execute policies for mines. Wired into these governance and decisionmaking structures is also the heavy representation of the strong mining sector, manifested through the influential mining association SweMin, which again feeds back in an interesting way to the central government of Sweden, since the government is the owner of Sweden's largest mining company.

On the other hand, waste management has been a matter of disposal and removing garbage from humans, and thus an environmental issue governed by and organized under a regulatory structure consisting of the Ministry of Environment and its Environmental Protection Agency. The recycling sector, however, is fragmented with a few large actors, who rarely share agendas, and several smaller scrap yards with limited possibilities to engage in advocacy. The responsible authority for the extraction of minerals is thus different depending on whether they are found in the underground or in the built environment. The different cultures, attitudes, knowledge, experiences and approach to activities (business vs. hazardous) found in these authority structures have resulted not only in a clear separation of the mine and the landfill, but also one being enacted as a desirable business issue, to be supported, and the other as undesirable hazardous issue, to be avoided, notwithstanding any other similarities between them.

\section{Concluding discussion}

To briefly summarize the above discussion, the overarching research interest underpinning this paper concerns the reflected and unreflected, as well as intentional and unintentional practices that contribute to organizing things as discrete objects of particular types. It further tries to articulate some of the consequences of these practices and - most importantly in this context - how a scholarly practice of unfolding objects in variegated topological registers in itself may contribute to challenging taken-for-granted object enactments. The conducted topological mapping of a Swedish mine and landfill have hopefully illustrated how every trajectory of landfill-becoming and minebecoming is in some aspects unique, with variegated concentrations of ore, differential institutional frameworks and physical as well as cultural surroundings - while in other aspects partially connecting or overlapping in various aspects at different instances. Thus, what is defined as a mine here, now might be something very different from a mine there, then - but, and here comes a further twist we like to add to this argument - it may also in practice actually be more similar to what goes on at a 
another place which is not at all defined as a mine, but rather called a landfill; and then again: very different from other landfills.

It is important to recognize that so-called After-ANT scholarship is far from the only scholarly approach concerned with issues such as these. Rather, the After-ANT way of going about research can be placed within an admittedly broad and variegated tradition of thinking, exemplifiable in recent years through the work of e.g. Rorty (1980), Latour (1986, part 2), Deleuze \& Guattari (1994), Law (2004) and Stengers (2011). What brings them together in all their heterogeneity is a care and concern for how we abstract, and the consequences of various practices of abstraction. In accordance with this tradition, abstractions such as 'mine' or 'landfill' or even 'any-objectwhatsoever' do not cut through the veils of the illusory to reach into some bedrock of the' really real', somehow illuminating the true identity of a specific thing - but rather add another layer of understanding to the world; a 'handle', 'foothold' or 'habit' of conducting oneself that comes into play in the constantly unfolding fate of the world. According to such an approach, the formation of new habits of abstraction that creatively reconfigure how we relate to the world in some aspect can also reverberate onto the practices for acting in the world that are or become attached to such abstractions within an ecology of practice.

What may mark out the specific contribution of After-ANT in such a context would perhaps be its irreductionist insistence on constantly referring back to the importance of empirical investigations and carefully attending to the minutiae of situated practice while aiming at transforming "all those whom it addresses into empirical witnesses, bringing to existence one or another aspect" (Stengers, 2011:145). For instance: The insight that there are patterns of similarities between many sites scattered over the world which are sometimes defined as mines, sometimes as landfills came to us as a result of the (theoretically inspired) empirical study of a concrete, specific mine and landfill mapped together in their fluid topologies. Similarly, the insight about how these partial connections (Strathern, 2004) then become subsumed under different (and differentiating) 'placeholders' that foreground some relations while obfuscating others, putting these different objects onto very different paths of becoming was a result of the (partial, always partial) mapping of the fire topology of the Zinkgruvan mine and the Gärstad landfill. This exercise helped us articulate the role played by the present Swedish legal framework in not only maintaining and locking in the present positions of these sites in material flows - although they potentially could be different - but also cementing the present way of organizing these relations as a given, taken for granted "collateral reality" (cf. Law, 2009b).

Given the above, we hope that we have been able to convincingly demonstrate that the After-ANT practice of mapping object topologies can provide concrete methodological equipment for researchers to act as "ontological guerillas" (Munk \& Abrahamsson, 2012) through (onto-)politicizing objects by teasing out their relational constitution and contesting their taken-for-grantedness. Even though valuable in itself, such a scholarly practice can perhaps best described as a subtle questioning of what is - a critique that more or less implicitly argues that what is at present might not be so good. Through doing so, a space is opened up, asking to be filled with suggestions along the lines of: what could then be a better way to go about things? What could become here? (A guerrilla rarely see an intrinsic value in overthrowing the established, it is primary a method for making way for establishing something new). Relating to the above discussion about interrogating practices and modes of abstraction, this ambition also resonates with Stengers' (2011) injunction that we should not just work towards "civilizing" our abstractions, to just point out in which aspects they can be considered unhelpful in a particular time and place - but to also actively work to "transform them" (Stengers, 2011:113). Hence, it is at this stage in the research process that we locate the second step of critical performativity that we have called ontological experimentation. So let's experiment! 
For instance, based on a recognition of the fluidity of resource-becoming starting-points and endpoints - how mines are to some extent also landfills and landfills, at least potentially, also mines - we wish to suggest that there might make good sense, at this point in time, to experimentalize our definitions of mines and landfills through loosening the distinction between the two, not just in theory but also in practice. This would then entail a proposal to do away with the strict differentiation between the mine seen as a resource and the landfill as a nuisance, and - following on from this - a questioning of the legal valorization of virgin mining operations, today given generous economic subsidies because of their status as a productive resource, and the legal discrimination of the mineral resource production already ongoing, and potentially expandable, in existing landfills.

Now why would this be a good idea? Writ large, the argument has to do with how humans need to become better at economizing those things we label as crucial resources, if we are not to very soon reach a situation that Richard Heinberg evocatively labels as "peak everything" (Heinberg, 2007). In the more specific and concrete, recycling for instance appears to have higher added value (Johansson et al., 2014) and less environmental impact (UNEP, 2013) than mining. This applies particularly well to recycling of disposed material in a landfill since the source of leachate is in addition partly removed, while the ground can be secured and opened up for economic activity or recreation. As for the Swedish mines, they most often occupy land previously used for other economic activities, such as the reindeer herding of the Swedish Sami national minority, risking degrading this land in such a way that this will prevent such usage for the foreseeable future.

In the face of the ecological challenges confronting humanity at the present, policy makers perhaps need to begin to think and act differently in relation to resources, and become more conscious about the far-reaching effects of often taken-for-granted or seemingly commonsensical object definitions that, upon second glance, we might do well to reconsider. So the question then becomes how we may find ways to practically re-enact mines and landfills in a way that for instance better promotes resource-making practices, e.g. for the extraction of metals that will contribute less to the degradation of crucial life-supporting systems on the planetary as well as the local scale, than what the currently dominant practices do.

On the basis of our topology mapping we can thus begin to tentatively identify a number of pivotal points through which mines and landfills presently either draw close to each other or become differentiated, points that could be utilized as critical instances where a difference could be made. For instance, resource flows in and out from the landfill could be made tax-exempt, like they presently are in the officially recognized mining industry. Also, to recognize the enormous amount of waste produced by mining, the mine could be made to legally-administratively approach the landfill and for example be targeted a form of landfill tax. Above all, natural resources could be managed under the same authority structure, regardless if they come from obsolete mobile phones, landfills or mines. Or, considering their vast socio-ecological impacts, mines should in that case perhaps be treated under the Ministry of Environment, while practices of recycling instead could be treated as a potential environmental business under the Ministry of Industry. In this case, mapping object topologies hence opens up an opportunity for concrete experimentation on how a landfill today can become a mine tomorrow, what is worthless waste today can become a valued resource and vice versa.

Performed in this manner, an ambition towards ontological experimentation in conjugation with practices of topology mapping thus contributes to putting into question what has previously been taken for granted. More concretely, it activates the immanent potential for alterity, change and transformation that "lurk in the interstices" (Stengers, 2011:420) of established abstractions, i.e. established object conceptualizations (Deleuze \& Guattari, 1994:28), such as 'mine' and 'landfill'. It then sets the stage for an event of thinking-differently around these issues with the help of the "unforeseen cuttings-out" provided with the help of topology mapping as a methodological device, 
creatively utilizing theory as a "relay from one practice to another" (Gilles Deleuze, cited in Foucualt, 1977).

But, and this is the final great caveat, we as researchers will have a harder time to perform this type of work, experimentally exploring potentialities and providing alternative avenues towards the future, if our quest is narrowly framed as a question of 'getting the picture right' rather than of allowing for a free and wild ontological experimentation (cf. Deleuze \& Guattari, 1994:105). This is the reason why we are worried about the increased interest in so-called Object-Oriented Philosophy (OOP) in parts of organizational studies. In our careful reading of the philosophical arguments underpinning OOP we are troubled to find that a central tenet of this elaborate metaphysical system is the idea that any "real object" is a coherent and self-sufficient thing existing in a "veiled underworld", in the form "a dark crystal veiled in a private vacuum" beyond any experience (Harman, 2011a:47). According to Graham Harman, the founder of OOP, what we humans (or anyone/-thing else) really encounter when we confront things are "mere sensual objects", confused and muddled copies of "real objects". ${ }^{10}$

Even if Harman has sometimes denied that it is possible to gain direct access to a proper apprehension of a 'real object', he nevertheless opens a backdoor in his system. In relation to his appropriation of Hussrl's concept of Eidos and his own metaphysical "fourfould" of "the quadruple object" Harman reaches the conclusion that even if "real objects" are inapprehensible in their completeness, "mere sensual objects" nevertheless always include certain "real qualities" (Harman, 2009: 203, 219) or "moments" belonging to the "veiled underworld":

"If the swirling lights and moods... are called accidents, the real features... can be called moments, and I hold that they are built of the same stuff as the qualities of real objects, thereby forming a link or ladder between the two layers of the world. The tension between an intentional object and its real moments is what Husserl calls eidos" (Harman, 2010: 16).

In relation to social science, the above would perhaps just amount to an interesting metaphysical speculation which in itself does not appear to make any real difference to how we conduct research, if it wasn't for the conclusions that Harman then draws from this insight:

"The question is under what conditions the real qualities of an unreal thing can be split up and rearranged into real objects, so that in this way the fictional objects of our mind can cross the bridge toward the real. As I have said, it happens all the time, and at other times fails. It is merely the way in which it happens or fails to happen that remains a puzzle" (Harman, 2011b:179).

Elsewhere, Harman even specifies which methods would be the appropriate ones for identifying the "real qualities" of "sensual objects", stating that "theoretical labor can disassemble or reverseengineer the bond between them" (Harman, 2011a:104). In relation to social scientific research practice it appears as if we are here suddenly not only told that there is a transcendent dimension that is more 'real' behind our lived realities, but we are also informed that "theory" can provide privileged access, a portal, into this more-real reality beyond lived experience. This metaphysical configuration that Harman offers thus does not only articulate the crucial task of humanities or social science scholarship as a "reverse engineering", where "the finished product that must be reverse-

\footnotetext{
${ }^{10}$ There is unfortunately not enough room for us to go into the details of the elaborate philosophical construct of OOP, as explicated by its leading proponent, Graham Harman. For a discussion on the core aspects of this philosophy, see e.g. Harman (2002) and Harman (2011a). The explicit anti-relational ontology underpinning OOP is specifically highlighted in Harman (2008). In e.g. Harman (2009) the author discussed his concept of "eidos," i.e., the revelation of "real" qualities in "sensual" objects. For a thorough philosophical critique of OOP, see further Wolfendale (2014).
} 
engineered is the world as we know it... so as to unlock the infrastructure of objects" (Harman, 2002:296), it further opens up for the possibility that even if 'everybody is getting things wrong (qua real objects), some may nevertheless be getting them less wrong than others' (by way of good theorizing).

To clarify, in some simplicity, what appears to be at stake here, a broadly defined pragmatist approach such as After-ANT would ask with William James: if no bell tolls to let us know for certain when truth is in our grasp, why solemnly wait for that bell? (James 1896); and would then proceed to engage in one form or another of immanent evaluation of the difference made by various ways of, for example, relating to the world and heterogeneous ways of conceptualizing objects. In contrast, Harman appears to fall in line with those philosophers who would champion an ambition to get 'as true a picture of reality as possible', with 'reality' here imagined to lie beyond the supposed distortions of lived experience (consisting of 'mere sensual objects') except for those who by way of theory are able to isolate 'real qualities'; apparently wagering on the possibility of discovering or constructing the proverbial 'Bell' or detector of 'real [i.e. transcendent] truth' (in the form of theory).

Whereas the first sketched, pragmatist, ontological experimentalist approach to social science would proceed by asking questions such as 'what does it do?' and 'can/should it be reconfigured?' as part of an always situated search for new ways of going on, the second approach instead roughly asks: 'what is it really?'; or put in OOP-related terms: 'are we getting the maximum of 'real' in our picture and scaling of as many 'mere accidental qualities' as possible? In relation to issues of social scientific research methodology, the above sketched contrast does not only again bring up the question of the purpose of social scientific investigation into clear relief; i.e. to come up with new ways of grasping, and potentially, going about things vs. getting the picture 'right', but also opens up towards the need for a critical vigilance regarding attempts at claiming epistemic privilege, i.e. supposedly superior access to reality, on the basis of abstract metaphysical reasoning (cf. Rorty, 1981).

So while both After-ANT and OOP could probably function as launching pads for the type of object analysis we have performed in the paper, the two approaches appear to point in profoundly divergent directions concerning what to make of the outcome of such studies. Where the weak metaphysical commitments of After-ANT would see such object-work as in different ways providing openings towards open discussions on how to creatively re-objectify what we today take for granted without any need for claims to the epistemic higher ground of 'getting-the-picture-more-right-thanyou-do', the specific metaphysical underpinnings of OOP instead appear to suggest that rather than opening up for experimentation, the analysis of objects should instead attempt to 'resolve' and hence close down further discussions by clearly identifying what an object 'really is' through sifting out or 'reverse-engineering' the truly real elements from the muddle of mere sensual accidents. So while we are highly sympathetic to Kärrholm's call for "more experimental object studies" (2013), given all the reasons sketched above, we are nevertheless very hesitant towards any suggestion of drawing upon OOP as a suitable source of inspiration in this endeavor. ${ }^{11}$

To conclude, we would therefore caution critical organizational scholars seeking to discuss important matters such as the relational biographies of things (pace Humphries \& Smith, 2014), or the potential of non-humans to surprise us (pace Pierides \& Woodman, 2012), or in any other manner interested in questioning the given order of things - to nevertheless refrain from drawing too heavily on OOP. ${ }^{12}$

\footnotetext{
${ }^{11}$ Here it should also be duly noted, that although drawing upon OOP as a source of inspiration, Kärrholm (2013) is quite aware of the strong ontological assumptions underpinning OOP and is highly suspicious of them, and his topological approach is very closely related to our own.

12 In relation to Humphries \& Smith's (2014) we are deeply sympathetic to the task they set before themselves, but we nevertheless find their reading of Harman's philosophy (over)generous. While they quite sensibly suggest that an "object biography is comprised of the sum of relationships that constitute it" (Humphries \&
} 
Our fear is that we may otherwise end up in a place where we risk displacing the possibility of free and wild ontological experimentation based on careful empirical work with the - in our eyes potentially stifling - reductionist project of 'identifying the really real' and squabbling over who has got the picture more right that OOP appears to lead towards. Therefore, we suggest a focus on further developing research methods that may function to destabilize our taken for granted perceptions of the world, but without any ambition to access some supposedly more real underlying reality. Such methods can then be employed as tools that can be used to generate normative shifts in concrete and specific cases by opening up potential, alternative trajectories towards the future; in the process generating some of the 'critical performativity' that is becoming increasingly called for in contemporary critical organizational studies.

\section{References}

Alcadipani, R., \& Hassard, J. (2010) “Actor-Network Theory, organizations and critique: towards a politics of organizing". Organization 17(4): 419-435.

Alm, J., Christéen, J., Collin, G. (2006) Landfill mining at Stena Gotthard's landfill in Halmstad. An environmental and economic evaluation. Master's Thesis. Linköping University.

Asdal, K., \& Moser, I. (2012) "Experiments in context and contexting". Science, Technology \& Human Values 37(4): 291-306.

ASWM (2008) “Högst 90 deponier kvar efter 2008/Maximum 90 landfills will remain open after 2008. Association for Swedish Waste Management". Avfall \& Miljö 1:8.

Bernander, M. (2012) "Boliden: väntad kopparhalt Aitik 2 kv på låga sidan/ Boliden: Expected copper concentration Aitik $2 \mathrm{kv}$ on the low side". Affärsvärlden.

http://www.affarsvarlden.se/hem/nyheter/article3468459.ece (accessed on 9th September 2014).

BGS (2013) World Mineral Production 2006-2011. British Geological Survey. United Kingdom.

Callon, M. (2002) “The economy of qualities". Economy and Society 31(2): 194-217.

de la Bellacasa, M. P. (2011) "Matters of care in technoscience: Assembling neglected things". Social Studies of Science 41(1): 85-106.

de la Bellacasa, M. P. (2012) "Nothing comes without its world': thinking with care". The Sociological Review 60(2), 197-216.

de Laet, M., \& Mol, A. (2000) "The Zimbabwe bush pump mechanics of a fluid technology". Social Studies of Science 30(2): 225-263.

Deleuze, G. \& Guattari, F. (1994). What is philosophy?. London: Verso.

Douglas, M. (1966) Purity and Danger: An Analysis of the Concepts of Pollution and Taboo. New York: Pantheon.

European Council (1999) "Council Directive 1999/31/EC of 26 April 1999 on the landfill of waste".

Smith, 2014:490), a proposition with which we can wholeheartedly agree, this translation of OOP underplays its main proponent's sustained argumentation against any form of relational understanding of the world (see e.g. Harman, 2002; 2008) 
Foucault, M. (1977). Language, counter-memory, practice: selected essays and interviews. Ithaca: Cornell Univ. P.

Fraser Institute (2014) "Survey of Mining Companies: 2013" http://www.fraserinstitute.org/researchnews/display.aspx?id=20902 (accessed on 9th September 2014).

Frändegård, P., Krook, J., Svensson, N., \& Eklund, M. (2013) "Resource and Climate Implications of Landfill Mining". Journal of Industrial Ecology 17(5): 742-755.

Gummesson, C. (2014) Personal contact with Carina Gummesson, environmental officer at Östergötland county.

Gunnarsson, M., Gunnarsson, E. (2007) Zinkgruvan Mining 1857-2007. Skyllberg: Bild och Kultur AB.

Haraway, D. (2013) Presentation given for the John E. Sawyer Seminar on the Comparative Study of Cultures "Indigenous Cosmopolitics: Dialogues About the Reconstitution of Worlds", UC Santa Cruz, $20^{\text {th }}$ of May 2013.

Harman, G. (2002) Tool-Being: Heidegger and the Metaphysics of Objects. U.S, Open Court Publishing Co.

Harman, G. (2008) "DeLanda's ontology: assemblage and realism". Continental Philosophy Review 41(3): 367-383.

Harman, G. (2009) Prince of Networks: Bruno Latour and metaphysics. Melbourne: re.press.

Harman, G. (2010). Time, space, essence, and eidos: A new theory of causation. Cosmos and History: The Journal of Natural and Social Philosophy, 6(1), 1-17.

Harman, G. (2011a) The Quadruple Object. Winchester: Zero Books.

Harman, G. (2011b). The Road to Objects. Continent., 1(3), 171-179.

Heinberg, R. (2007) Peak Everything: Waking up to the century of declines. Gabriola Island, B.C.: New Society Publishers.

Hetherington, K. (2004) "Secondhandedness: consumption, disposal, and absent presence." Environment and Planning D: Society and Space 22(1): 157- 173.

Hird, M. (2013) "Environmental ethic of vulnerability". Ethics and the Environment 18(1): 105-124.

Hudson, R. (2001) Producing Places. Guilford Press.

Humphries, C., \& Smith, A. C. (2014) "Talking objects: Towards a post-social research framework for exploring object narratives". Organization 21(4), 477-494.

Jacobs, J. M. (2006) "A geography of big things". Cultural Geographies 13(1): 1-27.

Johansson, N., Krook, J., Eklund, M. (2014) "Institutional conditions for Swedish metal production: a comparison of subsidies to metal mining and metal recycling". Resource Policy 41: 72-82. 
Karlsson, P., Åslund., P. (2014) The economical and environmental conditions for landfill mining. Master's Thesis. Linköping University.

Kärrholm, M. (2013) "Building type production and everyday life: rethinking building types through actor-network theory and object-oriented philosophy". Environment and Planning D 31(6): 1109 1124.

Latour, B. (1987) Science in Action: How to Follow Scientists and Engineers through Society. Cambridge, Mass.: Harvard University Press.

Latour, B. (2004) Politics of Nature: How to Bring the Sciences into Democracy. Cambridge, Mass.: Harvard University Press.

Latour, B. (2005) Reassembling the Social. New York: Oxford University Press.

Law, J. (1992) "Notes on the theory of the actor-network: Ordering, strategy, and heterogeneity". Systems Practice 5(4): 379-393.

Law J. (2002a) “Objects and Spaces". Theory, Culture and Society, 19: 91-105.

Law, J. (2002b) Aircraft Stories. Decentering the Object in Technoscience. Durham and London: Duke University Press.

Law, J. (2009a) "The Greer-Bush Test: on Politics in STS", http://www.heterogeneities.net/publications/Law2009TheGreer-BushTest.pdf, (accessed on 9th September 2014).

Law, J. (2009b) Collateral realities. Lancaster: Department of Sociology, Lancaster University. Http://www.heterogeneities.net/publications/Law2009CollateralRealities.pdf (accessed 9th September 2014.)

Law. J., Mol, A. (2001) "Situating technoscience: an inquiry into spatialities". Environment and planning. Part D, Society and Space 19: 609-621.

Law, J., Singleton, V. (2005) “Object lessons”. Organization 12(3): 331-355.

LKAB (2013) Korta fakta om LKAB/Brief facts on LKAB. http://www.Ikab.com/om-oss/Korta-fakta/ (accessed on 9th September 2014).

Lundberg, B. (1984) I hygienens tjänst: renhållning i Linköping under 75 år/In the service of hygiene: sanitation in Linköping during 75 years. Tekniska Verken, Linköping

Lundin Mining (2012a) Zinkgruvan Mine: Summary report. September 2012.

http://www.lundinmining.com/i/pdf/Summary Report Zinkgruvan.pdf (accessed on 9th September 2014).

Lundin Mining (2012b) Zinkgruvan Mine Operating Statistics. Fourth Quarter December 31, 2011. http://www.lundinmining.com/s/QOU.asp?ReportID=509795 (accessed on 9th September 2014).

Marres, N. (2013) "Why political ontology must be experimentalized: On eco-show homes as devices of participation". Social Studies of Science 43(3): 417-443. 
Matsuno, Y., Daigo, I., Adachi, Y., 2007 Application of Markov chain model to calculate the average number of times of use of a material in society-An allocation methodology for open-loop recyclingPart 2: Case study for steel. International Journal of Life Cycle Assessment 12(1), 34-39.

Merriam Webster dictionary (2014) Keywords: "Landfill" and "Mine". Online: http://www.merriamwebster.com/ (accessed on 9th September, 2014)

Mol, A. (1994) 'Ondertonen en Boventonen, over empirische filosofie'. In: D. Pels, G. de Vries, red. Burgers en vreemdelingen, opstellen over filosofie en politiek. Amsterdam: Van Gennep: 77-84

Mol, A. (1999) 'Ontological Politics. A Word and Some Questions', in J. Law and J. Hassard (eds.) Actor Network Theory and After. Oxford: Blackwell: 74-89.

Mol, A., Law, J. (1994) "Regions, networks and fluids: Anaemia and social topology" Social Studies of Science 24(4): $641-671$.

Moreira, T. (2004) "Surgical monads: A social topology of the operating room" Environment and Planning D: Society and Space 22: $53-69$.

Müller, A. (2013) Smutsiga miljarder: den svenska gruvboomens baksida/Dirty billion: the backside of the Swedish mining boom. Skellefteå: Ord\&visor förlag .

Mumford, L. (1934) Technics and Civilization. New York: Harcourt Brace.

Munk, A. K., \& Abrahamsson, S. (2012) “Empiricist Interventions: Strategy and Tactics on the Ontopolitical Battlefield”. Science Studies 25(1), 52-70.

Nilsson, M. (2014) Personal communication with Marlene Nilsson, environmental officer at Örebro county.

Pierides, D., \& Woodman, D. (2012). Object-oriented sociology and organizing in the face of emergency: Bruno Latour, Graham Harman and the material turn. The British Journal of Sociology 63(4): 662-679.

Rorty, R. (1980). Philosophy and the mirror of nature. Oxford: Blackwell.

Rorty, R. (1981) Method, Social Science and social hope. Canadian journal of Philosophy, 11(4): 569588.

SCS (1991) Minerallagen/Mineral Act 1991:45. Swedish Code of Statutes.

SCS (1998) Miljöbalken/Environmental Code 1998:808.

SCS (1999) Lag om skatt på avfall/ Act on waste tax 1999:673.

SCS (2001) Förordning om deponering av avfall /Ordinance on waste deposition 2001:512.

SEPA (1973) Beslut/Decision Nr215 DNR1878-82-73-0580. Swedish Environment Protection Agency. Solna: Statens Naturvårdsverk. 
SEPA (2012) Avfall I Sverige 2010/Waste in Sweden 2010. Naturvårdsverket. Bromma: CM Gruppen $A B$.

SGU (2011) Verksamhetsberättelse och årsredovisning 2010/Annual Report 2010. The Geological Survey of Sweden: Sveriges Geologiska Undersökning. KPH Trycksaksbolaget AB: Uppsala.

SGU (2012a) Bergverksstatistik 2011/Statistics of the Swedish Mining Industry 2011. Imprima Visuell Kommunikation AB: Solna.

SGU (2012b) Verksamhetsberättelse och årsredovisning 2012/Annual Report 2012. Sveriges geologiska undersökning. Elanders Tryckeri: Mölnlycke.

Spicer, A., Alvesson, M., \& Kärreman, D. (2009). "Critical performativity: The unfinished business of critical management studies". Human Relations 62(4), 537-560.

SR, 2010. Svårt för markägare att stoppa gruvor/ Difficult for landowners to stop mines. Swedish Radio 2010-08-20. Online:

http://sverigesradio.se/sida/artikel.aspx?programid=83\&artikel=3935738 (accessed on 9th September 2014)

Stengers, I. (2011). Thinking with Whitehead: a free and wild creation of concepts. Cambridge, Mass.: Harvard University Press.

Strathern, M. (2004) Partial Connections (updated ed.). Walnut Creek: Alta Mira.

Swedish Government (2004) Ändringar i minerallagen/ Changes in the Mineral Act. Proposition from the government to the parliament. Proposition 2004/05:40

Swedish Government (2013) Sveriges mineralstrategi/The Swedish mineral strategy. Elanders; Mölnlycke.

Tanha, A., Zarate, D. (2012) Landfill Mining: Prospecting metal in Gärstad landfill. Master thesis. http://liu.diva-portal.org/smash/record.jsf?pid=diva2:577243 (accessed on 9th September, 2014).

Tekniska Verken (2012) Gärstad avfallsanläggning, Miljörapport 2011/Gärstad waste facility, Environmental Report 2011. Linköping: Tekniska Verken.

Tekniska Verken (2013) Gärstad avfallsanläggning, Miljörapport 2012/Gärstad waste facility, Environmental Report 2012. Linköping: Tekniska Verken.

UNEP (2013) Environmental Risks and Challenges of Anthropogenic Metals Flows and Cycles. International Panel for Sustainable Resource Management. Nairobi, Kenya.

Wagner, T. P., \& Raymond, T. (2015). Landfill mining: Case study of a successful metals recovery project. Waste Management, in press.

Wolfendale, P. (2014) Object-Oriented Philosophy: The Noumenon's New Clothes. TJ International, Padstow.

Woolgar, S., Lezaun, J. (2013) "The wrong bin bag: A turn to ontology in science and technology studies?" Social Studies of Science 43(3): 321-340. 
Zapata Campos, M. J. (2013) "The function of waste urban infrastructures as heterotopias of the city: narratives from Gothenburg and Managua", in M.J. Zapata Campos \& C. M. Hall (2013) Organizing Waste in the City: International Perspectives on Narratives and Practices. London: Policy Press. 